\title{
APRENDENDO A SER AFETADO: CONTRIBUIC̣ÕES PARA A EDUCAÇÃO EM CIÊNCIAS NA EDUCAÇÃO INFANTIL
}

\author{
Francisco Ângelo Coutinho* \\ Universidade Federal de Minas Gerais (UFMG), Belo Horizonte - MG, Brasil \\ Maria Inês Mafra Goulart"* \\ Universidade Federal de Minas Gerais (UFMG), Belo Horizonte - MG, Brasil \\ Alexandre Fagundes Pereira"** \\ Universidade Federal de Minas Gerais (UFMG), Belo Horizonte - MG, Brasil
}

RESUMO: $O$ vínculo entre educação científica e educação infantil tem se constituído de modo tímido. Isso porque, muitas vezes, pensa-se equivocadamente que a maneira como a criança pequena interroga e investiga o mundo à sua volta não é apropriada. No entanto, fazendo uso da teoria ator-rede e de sua concepção de aprendizagem, analisamos episódio no qual crianças de 4 e 5 anos estavam engajadas na exploração de pistas deixadas em um jardim de uma Unidade Municipal de Educação Infantil. Nossos achados indicam que as crianças participam ativamente de atividades investigativas e aprendem a ser afetadas pelos elementos constitutivos do espaço designado para a exploração. Além disso, as crianças foram capazes de transformar os objetos tecnológicos disponibilizados em instrumentos científicos. Nossa análise foi possível por romper com uma concepção de aprendizagem como apropriação conceitual. Nesse sentido, procuramos entender a aprendizagem como capacidade de ser afetado e, portanto, como construção de um corpo.

Palavras-chaves: Educação infantil. Aprendizagem de ciências. Teoria atorrede. Afecção.

http://dx.doi.org/10.1590/0102-4698155748

Elocation-id - e155748

"Doutor em Educação. Professor da Faculdade de Educação da UFMG. Membro do Grupo de pesquisas sobre os Processos e Relações na Produção e Circulação do Conhecimento. E-mail: < coutinhogambiarra@gmail.com> .

"“Doutora em Educação. Professora da Faculdade de Educação da UFMG. Membro do núcleo de Estudos e Pesquisas em Infância e Educação Infantil (NEPEI). E-mail: <marinesmg@gmail.com>.

** *Licenciado em Ciências Biológicas. Mestrando em Educação pela UFMG. Núcleo de Estudos e Pesquisas em Infância e Educação Infantil (NEPEI). E-mail: < alexandre210490@yahoo.com.br > . 


\section{LEARNING TO BE AFFECTED: CONTRIBUTIONS TO SCIENCE EDUCATION IN EARLY CHILDHOOD EDUCATION}

ABSTRACT: The link between Science Education and Early Childhood Education has been constituted in a timid way. This is because it is often thought that the way the young child investigates the world around him/ her is wrong or not appropriate. However, using the actor-network theory and its conception of learning in this study, we analyze an episode in which children aged 4 and 5 years old were engaged in the exploration of clues left in the courtyard of a Municipal Unit of Early Childhood Education. Our findings indicate that children actively participate in investigative activities and learn to be affected by the constituent elements of the designated space for exploration. More over, children were able to turn technological objects available on scientific instruments. Through our analysis, we were able to break away from the concept of learning as conceptual appropriation. In that sense, we sought to understand learning as an ability to be affected and, therefore, as building a body.

Keywords: Early Childhood Education. Science learning. Actor-network theory. Affected theory.

\section{INTRODUCุÃO}

O vínculo entre educação científica e educação infantil tem se constituído de modo tímido. Muitas vezes porque se nega às crianças a oportunidade de participar produtivamente de práticas de ensino/ aprendizagem de ciências, pois se pensa equivocadamente que a maneira como a criança pequena interroga e investiga o mundo à sua volta não é apropriada. Roth e colaboradores (2013, p. V) argumentam que muito dessa visão pode ser creditada aos trabalhos de Piaget que, ao invés de estudar as crianças no contexto do seu próprio mundo, a via a partir das lentes da ciência dos cientistas. Tese semelhante é defendida por French e Woodring (2013, p. 182, tradução nossa), segundo os quais

[...] um grande obstáculo ao ensino de ciências na primeira infância tem sido a dependência da teoria piagetiana como uma abordagem principal para a compreensão do desenvolvimento infantil articulada com uma definição de ciência que envolve alguma combinação de princípios abstratos e experimentação controlada com múltiplas variáveis. ${ }^{1}$

Igualmente, Metz (1995), em um trabalho de revisão, já apontava para o fato de que os estudos que focam a incapacidade das crianças de aprenderem ciência estarem assentados ou em uma falsa concepção sobre o processo de desenvolvimento das crianças ou em uma visão ingênua sobre a natureza da ciência. Esses estudos 
criticados por Metz (1995) também se ancoram no legado da epistemologia de Piaget, que toma o processo de conhecer como a construção progressiva de estruturas cognitivas mentais realizada pelo indivíduo apartado da sua experiência cotidiana. Desse ponto de vista, parece razoável se pensar que as crianças pequenas não estão aptas a uma educação científica, pois elas ainda não possuem estruturas cognitivas condizentes com os conceitos científicos, gerando, como consequência, uma visão de mundo equivocada, alternativa, provisória, inacabada. Essa ótica caracteriza a criança como incompleta ou, no máximo, possuidora de concepções intuitivas.

Devemos lembrar que, especialmente durante as décadas de 1980 e 1990, os estudos sobre as concepções alternativas dominaram a pesquisa sobre educação em ciências e matemática. Segundo Mortimer (2000), apesar da grande variedade de diferentes visões que aparecem na literatura sob o mesmo rótulo, existem pelo menos dois aspectos que parecem ser compartilhados pelas diferentes abordagens:

[...] a aprendizagem se dá através do ativo envolvimento do aprendiz na construção do conhecimento; as ideias prévias dos estudantes desempenham um papel fundamental no processo de aprendizagem, já que essa só é possível a partir do que o aluno já conhece. (MORTIMER, 2000, p. 36)

A partir desse modelo de aprendizagem, desenvolveu-se um modelo de ensino para lidar com as concepções dos estudantes que procurava transformá-las em conceitos científicos: o modelo da mudança conceitual. Proposto como um modelo para explicar ou descrever "as dimensões substantivas do processo pelo qual os conceitos centrais e organizadores das pessoas mudam de um conjunto de conceitos a outro, incompatível com o primeiro" (POSNER et al., 1982, p. 211). "Mudança conceitual", na década de 1980 e em parte da década de 1990, "tornou-se sinônimo de aprender ciência” (NIEDDERER; GOLDBERG; DUIT, 1991).

O presente trabalho caminha na direção oposta a essa, mobilizando alguns referenciais teóricos e metodológicos e, a partir de estudos empíricos, propõe acompanhar os processos de aprendizagem de ciências e sobre a ciência na Educação Infantil. Porém, levar a efeito uma aproximação entre educação científica e educação infantil não significa acreditar ingenuamente que as crianças participam em atividades científicas do mesmo modo que adolescentes ou adultos. De fato, o desafio que nos colocamos é justamente o de não pressupor que o adulto seja o parâmetro para avaliar a aprendizagem e a participação das crianças. Dito de outro modo, não partimos de uma 
concepção a priori do significado de aprender ciências; pelo contrário, nos interessa possibilitar condições e situações de aprendizagem e convidar as crianças a explorar suas formulações.

O que aqui se propõe, portanto, é um olhar que busca compreender os processos de aprendizagem de ciências por meio dos valores e conhecimentos produzidos no universo cultural das próprias crianças. Desse modo, ao invés do foco em processos de apropriação de uma nova cultura, da aquisição de conceitos ou de formas de pensamento, nosso intento é analisar os modos de participação das crianças dentro de suas possibilidades de agir.

\section{A CRIANÇA EM SEUS PRÓPRIOS TERMOS}

Como vimos, durante a década de 1980, com o apogeu dos estudos envolvendo concepções alternativas dos estudantes e modelos de mudança conceitual para lidar com essas concepções no processo de ensino-aprendizagem, os pesquisadores tenderam a enfatizar o processo individual de construção de conhecimento. Uma preocupação era estudar como as concepções alternativas dos estudantes poderiam ser modificadas, por exemplo, por meio da criação de conflitos entre essas concepções e os resultados experimentais ou entre diferentes estruturas cognitivas relacionadas aos mesmos fatos (MORTIMER, 1995).

$\mathrm{Na}$ década de 1990, no entanto, alguns pesquisadores começaram a perceber que essa abordagem não dava conta da complexidade das relações envolvidas no processo de aprendizagem em sala de aula (MORTIMER, 1995). Alguns desses trabalhos procuravam incorporar a dimensão sócio-interacionista à análise do processo de ensino (EDWARDS; MERCER, 1987; MORTIMER, 1995; MORTIMER; CARVALHO, 1996; NEWMAN; GRIFFIN; COLE, 1989; ROMANELLI, 1992; SCOTT, 1992). Segundo esses trabalhos, a construção do conhecimento em sala de aula passa por um processo no qual os alunos apropriam-se dos significados e da linguagem do professor na construção de um conhecimento compartilhado. Dessa perspectiva, a visão é a de que, para a superação dos obstáculos à aprendizagem dos conceitos científicos, faz-se necessário um processo de interações sociais mediadas pelo discurso, no qual o professor tem o papel fundamental de representante da cultura científica. Assim, aprender ciências é visto não como um processo de transmissão de conhecimentos, mas como um fenômeno de "enculturação" (DRIVER et al., 1994; HODSON; HODSON, 1998), ou seja, a entrada numa nova cultura, diferente da cultura de senso comum. 
Embora amplamente divulgada e aceita (veja-se, por exemplo, CAPECCHI; CARVALHO, 2006; CARVALHO, 2007) essa ideia de aprendizagem de ciências enquanto um fenômeno de enculturação, no que diz respeito à Educação Infantil, traz sérios problemas. Isso porque, nesse segmento da educação, ressaltamos a visão de criança como competente e participativa bem como procuramos inverter o foco do processo de escolarização. Isso significa enfrentar tanto o problema da transmissão do conhecimento quanto o da enculturação e pensar o espaço educacional como um ambiente que emerge de uma construção coletiva entre todos os envolvidos. Nesse processo, o professor procura adentrar no universo infantil, ser afetado pela experiência do grupo de crianças, potencializá-la e fortalecê-la.

Em trabalho anterior, Goulart e Roth (2010) já anunciam essa concepção quando apresentam um estudo em que uma prática coletiva entre crianças e professoras faz emergir um tópico curricular de exploração do mundo da natureza. $\mathrm{O}$ que chamou atenção nesse estudo foi a entrada da professora nos modos de ordenação com que as crianças interpretam o mundo e sua capacidade de potencializar sua demanda de conhecimento. Assim, não houve nesse processo uma pretensão de transmitir um conhecimento científico ou mesmo de trazer as crianças para uma presumida cultura científica.

Em outro estudo que também esboça um caminho diferente daqueles apresentados anteriormente, Coutinho e colaboradores (2014) investigaram crianças entre quatro e cinco anos enquanto utilizavam uma lupa para observar materiais coletados no jardim da escola. Nesse estudo, a ótica também se inverte e é possível examinar a formação de uma rede sociomaterial (constituída por humanos e não humanos), que oportunizou às crianças bem pequenas expandir suas formas de ver e de sentir o mundo. Nesse estudo, o que se percebe não é um processo de enculturação, mas a emergência de uma cultura científica própria das crianças na escola. Dito em outras palavras: por meio de uma ação coletiva, as crianças foram capazes de produzir uma interpretação própria sobre a natureza, uma interpretação que, ao mesmo tempo, se aproximava e se distanciava da forma concebida pelos adultos.

A ideia de aprendizagem de ciências como um fenômeno de enculturação também não se conforma com os achados do campo da sociologia da infância que destacam a necessidade de considerar as crianças como atores sociais plenos e, com isso, a ideia de enculturação apaga a complexidade de relações que se estabelecem entre as crianças, seus pares e os artefatos culturais que elas manipulam e exploram (veja-se, por exemplo, CORSARO, 1997). 
Em trajetória argumentativa semelhante, Pinto e Sarmento (1997, p. 20) ressaltam a necessidade de se considerarem as "culturas da infância", ou seja, a capacidade das crianças de produzirem interpretações próprias e distintas dos adultos sobre o mundo natural e social. Segundo os autores, as crianças são atores sociais que constroem sistemas organizados de conhecimentos e, portanto, são sujeitos capazes de produção simbólica e de crenças fundadas. $\mathrm{O}$ que se coloca então é a necessidade de focar como as culturas infantis produzem significações próprias, distintas das culturas adultas (vejase, por exemplo, BARBOSA, 2007).

Entre as propostas de estudos da infância, devemos destacar, ainda, a obra de Alan Prout. Esse autor também enfatiza que os novos modos de falar, escrever e representar a infância reconstroem a criança como mais ativa, socialmente participativa e capaz de produção de conhecimentos do que o que era permitido pelos antigos discursos que viam as crianças a partir de seus déficits (PROUT, 2005). Fazendo uso do conceito latouriano de "redes heterogêneas do social" (LATOUR, 1994, p. 6), Prout reconhece que a infância possui um caráter híbrido, não podendo ser dita nem natural, nem cultural. As ideias de Prout nos levam então à próxima seção, em que desenvolvemos os principais conceitos da teoria ator-rede de Latour.

\section{A TEORIA ATOR-REDE COMO REFERENCIAL TEÓRICO-METODOLÓGICO DE ANÁLISE DAS ORDENAÇÕES DA INFÂNCIA}

Segundo Prout (2010), a teoria ator-rede (TAR) de Latour fornece uma linguagem analítica para falar sobre a ordenação da infância que abandona a divisões e categorizações a priori e torna pensáveis as redes sociomateriais que hibridizam pessoas, adultos, crianças, corpos, mentes, artefatos, animais, plantas, arquiteturas etc. (PROUT, 2010). A TAR assevera que tudo o que existe são actantes $^{2}$ (humanos e não humanos) que só podem ser definidos performaticamente, ou seja, por aquilo que fazem em uma rede híbrida de interações. O que define um actante como tal não é uma essência ou um conjunto de propriedades necessárias e suficientes inerentes a ele, mas as relações entre as diversas entidades em ação (HARMAN, 2009 , p. 17). Portanto, um actante nunca pode ser compreendido como uma entidade isolada. Actantes estão sempre imersos em suas relações (HARMAN, 2009, p. 17) e devem ser compreendidos por suas "interferências interativas" (BENNETT, 2010, p. 21). Quando 
um actante se torna indispensável, de tal modo que vários outros se interligam a ele, dizemos que ele se tornou um ponto de passagem obrigatório (LATOUR, 2000, p. 214).

O pressuposto básico da TAR é que "social" deve ser definido como associação e compreendido em termos de rede, ou ator-rede, o que envolve uma heterogeneidade de elementos humanos e não humanos. Da perspectiva da TAR, o social e o cultural não são instâncias privilegiadas da realidade ou substâncias ou causas que explicam como as pessoas agem ou se relacionam. Pelo contrário, a sociedade e a cultura é que devem ser explicadas (LATOUR, 2005, p. 17-18).

Latour argumenta que a o pesquisador deveria, ao invés de utilizar categorias gerais como "social", "psicológico", "cultural", "ideológico" etc. para explicar os mais variados fenômenos que ocorrem na vida dos humanos, se deter na busca do entendimento das associações que estes estabelecem entre si e com os não humanos e de como estas associações se estabilizam gerando o social, o psicológico, o cultural, o ideológico etc. (veja-se, por exemplo, LATOUR, 2005, p. 45). O projeto analítico da TAR, portanto, é investigar como os actantes tornam-se relacionados a outros actantes formando redes e como, em certos casos, esse processo leva a estabilizações relativamente duráveis e extensas (BLOCK; JENSEN, 2011, p. 167).

As redes ou os atores-redes são formados por aquilo que Latour chama de "processos de translação", ou seja, um processo em que dois ou mais actantes tornam-se de tal modo relacionados que um exerce força sobre o outro. Isso significa que, para fazer parte de uma rede, os actantes devem ser reunidos de modo a trabalharem juntos, o que pode significar mudanças nas formas em que atuam (SISMONDO, 2010, p. 82).

\section{LEVANDO A TEORIA ATOR-REDE AOS DOMÍNIOS DA APRENDIZAGEM}

No início do presente artigo acreditamos ter dito o suficiente para apontar nossa discordância em relação à concepção de aprendizagem como transmissão de conhecimento, mudança conceitual, aquisição de formas de pensamento ou mesmo enculturação. Como já argumentamos, esta última torna-se problemática quando lidamos com crianças pequenas e quando nos atemos à teoria atorrede. Em primeiro lugar, essas crianças possuem modos próprios de interação com o mundo, com seus pares e com as instituições das quais fazem parte, criando nessas relações uma cultura própria. Em 
segundo lugar, com Prout e Latour, vimos que utilizar o conceito de cultura para entender o processo de aprendizagem é "colocar o carro na frente dos bois" ’3. Cultura é algo que deve ser explicado e não uma força ou entidade que cimenta a realidade dos humanos.

O que aqui se propõe, portanto, é um olhar que busca compreender os processos de aprendizagem de ciências por meio dos valores e conhecimentos produzidos no universo cultural das próprias crianças. Ao invés do foco em processos de apropriação de uma nova cultura, da aquisição de conceitos e de formas de pensamento, nosso intento é analisar os modos de participação das crianças em atividades de observação e exploração do ambiente.

Para essa análise precisamos, em primeiro lugar, apresentar o que se entende por aprendizagem segundo a TAR. Nessa abordagem, a aprendizagem não é identificada como um atributo humano individual. Melhor, o conhecimento é gerado e distribuído por meio de assembleias/reuniões de actantes (FOX, 2009, p. 31).

Para entendermos isso melhor, vamos recorrer a um exemplo estudado pelo próprio Latour (2004). Nesse estudo, Latour analisa o treinamento de experimentadores de fragrâncias para a indústria de perfumes; ou, nas palavras de Latour, treinamento "de narizes para a indústria" (LATOUR, 2004, p. 206). Segundo Latour, esse treinamento, que dura uma semana, é feito por meio de um kit de odores (malettes à odeurs), que contém uma "série de fragrâncias puras nitidamente distintas, dispostas de forma a poder passar-se do contraste mais abrupto ao mais suave" (LATOUR, 2004, p. 206), com o acompanhamento de um professor experiente. A partir de um nariz que não consegue identificar mais do que odores doces ou fétidos, rapidamente se obtém um "nariz" (un nę), ou seja, alguém capaz de discriminar um número crescente de diferenças sutis, e de distingui-las entre si, mesmo quando estão disfarçadas ou misturadas com outras.

A partir desse exemplo, Latour argumenta que as partes do corpo são aquisições progressivas "ao mesmo tempo em que as 'contrapartidas do mundo' vão sendo registradas de nova forma” (LATOUR, 2004, p. 207). Diz Latour: "Adquirir um corpo é um empreendimento progressivo que produz simultaneamente um meio sensorial e um mundo sensível" (LATOUR, 2004, p. 207). Assim, vale notar que, para Latour, o kit de odores torna-se coextensivo ao corpo do aprendiz. Graças ao kit e ao professor os aprendizes podem sensibilizar-se para distinções cada vez mais sutis. Nesse caso, ainda segundo Latour, o que os alunos aprenderam não foi tornarem-se 
mais atentos, mas a serem afetados, ou seja, efetuados pela influência das fragrâncias. "Antes do treino, os odores atingiam os aprendizes mas não os faziam agir" (LATOUR, 2004, p. 207).

Na concepção de Latour, a aprendizagem nos campos científicos é igualmente uma forma de "aprender a ser afetado". Também os químicos, físicos e biólogos precisam de professores, salas de aula, de instrumentos, da literatura, das conferências, dos laboratórios e de toda aquela coleção de coisas necessárias para que eles adquiram um corpo. Aprender ciência é aprender a ter um corpo, a ser posto em movimento por "novas entidades cujas diferenças são registradas de formas novas e inesperadas" (LATOUR, 2004, p. 209). Assim, continua Latour, "quanto mais artifícios estiverem presentes, mais sensações, mais corpos, mais afecções, mais realidades serão registradas" (LATOUR, 2004, p. 212). Isso porque, quanto mais mediações existem, se torna mais fácil adquirir um corpo que seja sensível aos efeitos de mais entidades diferentes. Para resumir em um vocabulário latouriano: quanto mais translações, mais o mundo se torna vasto ${ }^{4}$.

A leitura da TAR alinha-se, portanto, com outras abordagens que procuram desnaturalizar a noção de aprendizagem como um fenômeno mentalista, simbólico, imaterial. Nesse caso, como vimos, a TAR enfatiza que objetos, tecnologias, forças naturais, professores, alunos, merenda, amizades etc. estão todos suturados intimamente dentro do processo (FENWICK; EDWARDS; SAWCHUK, 2011, p. 117). O fenômeno da aprendizagem, portanto, é visto como um efeito de rede, como alguma coisa que emerge continuamente através de negociações, lutas e provas de força em inúmeros nós de possíveis conexões entre humanos e não humanos (FENWICK; EDWARDS; SAWCHUK, 2011, p. 117).

No que diz respeito à aprendizagem, portanto, a TAR assume uma posição monista da realidade. Em outras palavras, assume a impossibilidade de distinção substancial e funcional entre mente e matéria, entre sujeito e meio. Desse modo, precisamos pensar os não humanos como coparticipantes das ações e relações de aprendizagem, como coextensivos aos nossos corpos, e não meramente como meios de transporte entre o interno e o externo.

Essa postura é coerente com outras abordagens que emergiram nas últimas décadas. Hutchins (1993), por exemplo, desenvolveu uma abordagem conhecida como "cognição distribuída", segundo a qual a cognição não é uma propriedade de mentes individuais, mas uma ação dinâmica e contextualizada e localizada em relações distribuídas entre indivíduos e fontes sociais e físicas (por exemplo, livros, manuais, colaboradores, computadores, instrumentos de navegação 
etc.). Estudando como a navegação de uma embarcação é realizada, Hutchins percebeu que havia um esforço de cooperação entre os tripulantes e as ferramentas disponíveis no navio. Cada tripulante tem responsabilidades específicas e manipula ferramentas apropriadas para a tarefa que executa. O resultado dessa cooperação é o conhecimento da comunidade sobre como navegar o navio. É o conhecimento do grupo, bem como as ferramentas no navio, que permitem a navegação da embarcação. Hutchins concluiu que mentes individuais não podem ser consideradas como o lócus de estruturas que organizam o pensamento.

\section{ANÁLISE DOS PROCESSOS DE EXPLORAC̣ÃO DO MUNDO NATURAL: APRENDENDO A SER AFETADO}

Até este momento, discutimos as questões teóricas sobre a aprendizagem de ciências por crianças pequenas, apontando o referencial teórico da TAR como potente ferramenta analítica para esta discussão. Nesta seção, fazemos uma breve apresentação acerca da produção dos dados empíricos da pesquisa. Apresentamos também o evento selecionado para análise que nos possibilitou discutir uma concepção de aprendizagem baseada na noção de ser afetado.

\section{A PESQUISA COLABORATIVA/FORMATIVA}

Os dados que serão apresentados e analisados a seguir foram obtidos a partir de uma pesquisa colaborativa/formativa, ainda em andamento. Essa abordagem tem por objetivo levar a pesquisa para dentro da Escola Básica com vistas à provocação de mudanças efetivas nas práticas pedagógicas. $\mathrm{Na}$ perspectiva da Pesquisa Colaborativa, como aponta Ibipaina (2008), os participantes trabalham coletivamente, desenvolvendo tarefas e buscando objetivos comuns. O resultado desse trabalho conjunto são ações conduzidas pelo grupo, que se organiza por meio de uma liderança compartilhada. Assim, por meio da colaboração entre pesquisadores da universidade (professores e alunos) e professoras da Educação Infantil da rede pública, procuramos refletir sobre a prática em curso criando uma rede propícia para o aprendizado de todo grupo.

Este estudo vem sendo realizado em uma Unidade Municipal de Educação Infantil (UMEI), localizada na cidade de Belo Horizonte. A metodologia colaborativa conta com a participação de professores da Faculdade de Educação, alunos da graduação e da pós-graduação dos cursos de Pedagogia, Psicologia e Ciências Biológicas bem como 
de professoras da própria escola que, juntas, buscam captar a demanda de conhecimento das crianças expressa por meio da curiosidade infantil e transformá-la em atividades de investigação.

O desenho da investigação contou com um aporte etnográfico tanto no que se refere ao tempo de permanência na escola (um ano e meio, no total) quanto à aceitação do grupo de professoras e crianças (CORSARO, 1997; CORSARO, 2002). Em coerência com esta forma de pesquisar, também a apresentação de nossas observações procurou seguir um relato etnográfico. Os dados produzidos para o presente artigo foram registrados durante três meses de permanência em uma turma de crianças entre 4 e 5 anos durante o segundo semestre de 2014. A gravação em vídeo das atividades realizadas com as crianças constituiuse como o principal material de análise dos dados. As conversas nas reuniões de professoras e todo o material produzido pelas crianças desenhos, fotos, cartazes - constituíram-se como fontes secundárias para a triangulação dos dados. É dentro desse contexto que iremos descrever e analisar alguns aspectos de um projeto desenvolvido com crianças entre 4 e 5 anos, denominado pela turma de "Arte Rupestre".

\section{A EMERGÊNCIA DA NOÇÃO DE PISTAS}

O projeto teve início por uma provocação da professora ao explorar com as crianças o material de artes da escola que fica armazenado em uma sala. Com o objetivo de introduzir as crianças nos primórdios da produção artística humana, a professora decidiu iniciar o projeto, apresentando aquela que é considerada uma das primeiras manifestações artísticas da história, a pintura rupestre. Mas o que realmente chamou a atenção das crianças foi a existência desse um momento singular da humanidade, ou seja, o "homem das cavernas". Procurando ter uma escuta apurada da curiosidade da turma, mudamos o curso do projeto e passamos a construir atividades que dialogassem com as questões trazidas pelo grupo. Podemos ilustrar esta fase do projeto conforme a Figura 1.

FIGURA 1 - Desvio realizado pelas crianças quanto às intenções do projeto

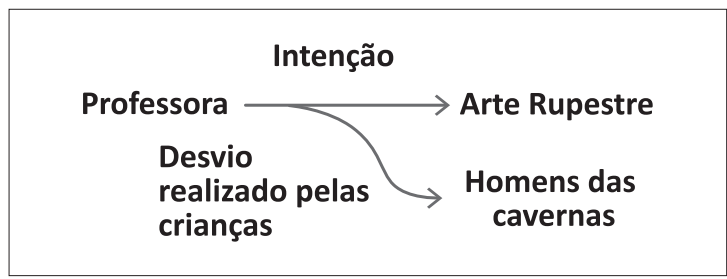

Fonte: Elaborado pelos autores deste trabalho. 
Assim, ao fazer a primeira provocação com a apresentação da pintura rupestre, a professora abriu um campo de possibilidades para ser explorado pelas crianças. Essas, por sua vez, redimensionaram a proposta ao focar a atenção questionando os hábitos de vida dos homens das cavernas: "como eles faziam para cuidar dos machucados se não havia band-aid?" "Como tomavam banho e escovavam os dentes?" Colocadas como prioridade, as questões das crianças deram novos direcionamentos ao projeto. Um ponto essencial, apresentado pela turma, foi o questionamento sobre a possibilidade de se obter todo esse conhecimento uma vez que os homens das cavernas viveram há muitos anos. Foi então que um dos pesquisadores participantes, da área de biologia, trouxe o elemento-chave de investigação para as crianças: a partir da investigação das pistas deixadas pelos homens das cavernas podíamos deduzir e entender seus hábitos de vida. Assim, as novas questões postas pelas crianças, o desvio da professora e do projeto inicial e a entrada de um novo actante, o pesquisador, dão um novo rumo ao projeto, como se pode ver na Figura 2.

FIGURA 2 - Desvios e associações mobilizados pelas crianças e construção de uma nova prática investigativa

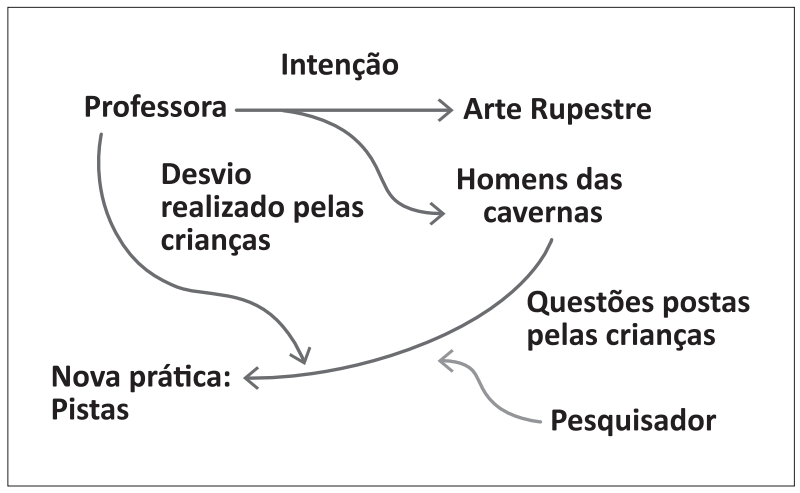

Fonte: Elaborado pelos autores deste trabalho.

Com o objetivo de aprofundar e vivenciar o que seria uma pista, ampliando a explicação dada, propusemos a prática de investigação no bosque da UMEI para que as crianças pudessem experienciar o fato de que as pistas contam histórias. Para isso a professora mobilizou outra turma de crianças que brincaram no bosque no dia anterior e lá deixaram os objetos e brinquedos, que se transformaram em pistas para serem investigadas. No dia seguinte, as crianças foram separadas em duplas para proceder à investigação no bosque. Cada dupla recebeu como 
instrumentos de investigação um par de luvas, uma lupa, uma câmera fotográfica e um saco plástico, para que pudessem observar, registrar e coletar as pistas. Foram dadas instruções básicas de como eles deveriam manusear as pistas encontradas, relacionando a prática com o trabalho dos cientistas. O destino do projeto inicial e os novos e imprevistos actantes mobilizados nesse momento podem ser vistos na Figura 3.

FIGURA 3 - Reconfiguração do projeto inicial e a entrada de novos e imprevistos actantes

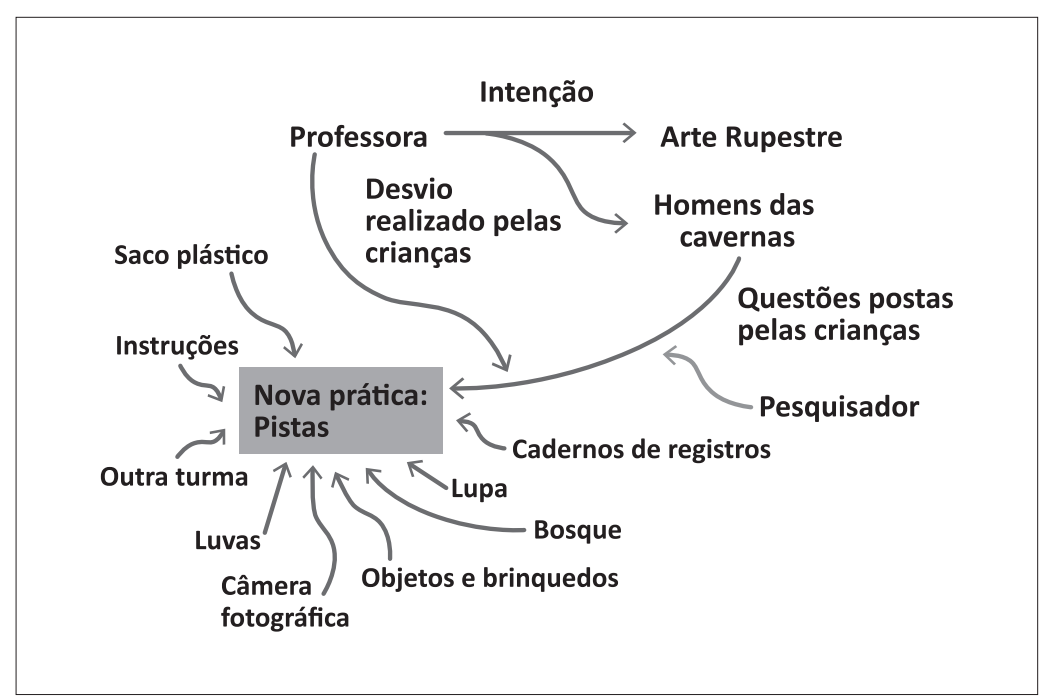

Fonte: Elaborado pelos autores deste trabalho.

Após receberem as instruções, foram para o bosque e começaram a busca por todo e qualquer elemento que julgavam ser uma pista, sem nenhum tipo de orientação dos adultos ali presentes; brinquedos, paus, pedras, folhas, mangas inteiras, cascas e caroços de mangas, pegadas e marcas de mãos, penas, entre outros. As pistas foram então guardadas, e, a partir daí, em outro momento, as crianças tiveram a oportunidade de separá-las em duas categorias: pistas humanas e pistas da natureza e elaborar hipóteses sobre a história do que havia acontecido no bosque no dia anterior.

\section{APRENDENDO A SER AFETADO}

Nesta seção analisaremos um episódio que foi selecionado para ilustrar o processo empreendido especialmente pela participação ativa de duas crianças, Gustavo ${ }^{5}$ e Eliane, que buscam dar significado para a ideia de pista. Nesse processo, podemos observar: a formação 
de uma rede híbrida de interações composta por crianças, câmeras fotográficas, brinquedos, pedras, muros, pessoas; as condições pelas quais as crianças foram afetadas - movimentação de seus corpos, manipulação de instrumentos, mediações pela fala com outras crianças e adultos, encantamento; a aprendizagem das crianças, ou seja, o efeito, produzido pela rede em constante negociação, que gerou conhecimentos que tornaram o mundo das crianças mais vasto.

\section{Formação da rede híbrida}

O episódio se inicia com a turma descendo para o bosque (pátio da escola com chão de terra e que possui algumas árvores, denominado pela comunidade escolar de "bosque"), aos 19 min52s do início da atividade. Nos 15 minutos iniciais, as crianças, em roda, retomaram pontos importantes que já haviam sido explorados no projeto e se prepararam para a descida até o bosque. O pesquisador, junto com a professora, deu instruções de como as crianças deveriam fazer ao se deparar com uma provável pista: observar atentamente, fotografar, coletar e estocar em um saco plástico. Para isso as crianças foram separadas em duplas e ganharam alguns artefatos: uma lupa para ampliar as possibilidades de observação do objeto, uma câmera fotográfica, uma luva para coletar o material achado e um saco plástico para estocagem.

Gustavo e Eliana formam uma dupla para investigar as pistas deixadas por outras crianças no dia anterior. Aos $19 \mathrm{~m} 52 \mathrm{~s}$, já no bosque, eles iniciam a busca e, em seguida, acham uma primeira possível pista: uma madeira com formato retangular. Eles a observam, registram, tirando uma foto, e a recolhem. A madeira possui algo peculiar: colada em sua superfície, há alguma coisa parecida com duas patinhas de uma pequena ave. Esse primeiro achado, de certa forma, misterioso, coloca a dupla dentro da proposta da professora.

Nesses primeiros movimentos, podemos perceber a formação da rede híbrida de interações: a roda de crianças na sala, as instruções dos adultos, a formação de duplas, a distribuição de artefatos, o traslado da sala ao bosque passando pelo corredor, pela escada, pelo refeitório até chegar ao bosque. Ali o lugar se transforma. Ao invés de ser um espaço para o brincar, há uma investigação a ser conduzida. Gustavo e Eliane acham uma primeira pista. São membros ativos daquela comunidade formada por pessoas, instrumentos, objetos, árvores, pedras, muros. Esse movimento está registrado na Figura 4. 
FIGURA 4 - Formação da rede de interações

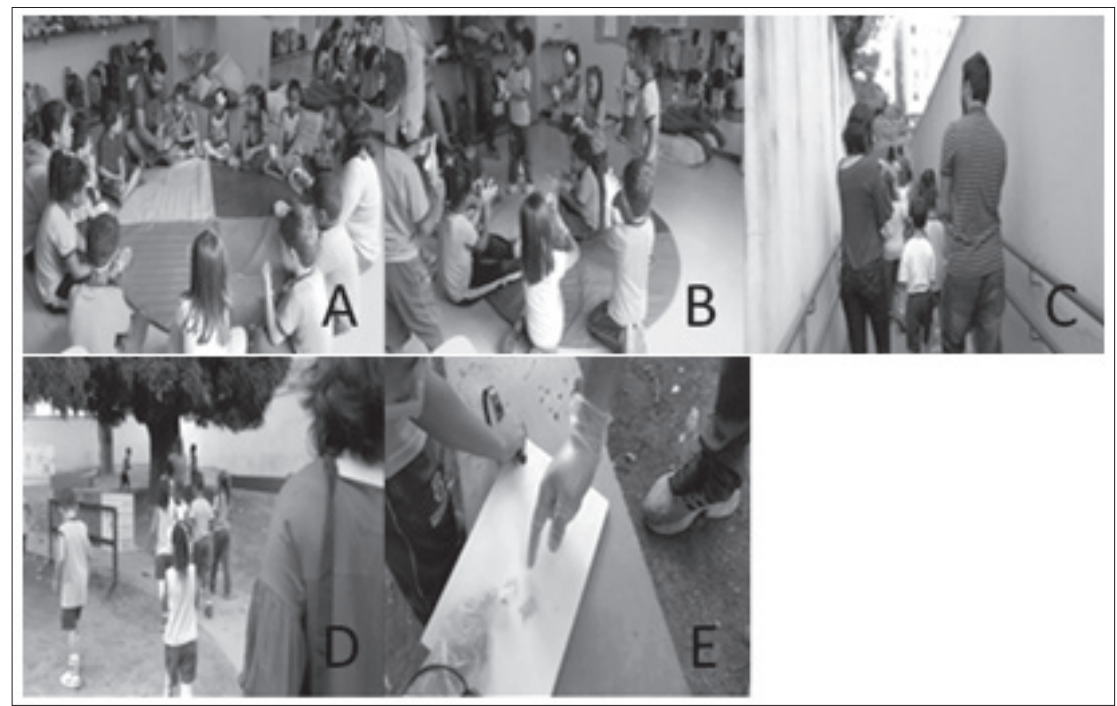

Legenda: Pesquisador orienta as crianças sobre os procedimentos da atividade $(A)$; Formação das duplas e distribuição dos artefatos (B); Crianças chegando ao bosque (C); Início da investigação (D); Primeira pista encontrada pela dupla Gustavo e Eliane (E). Neste momento, todos os actantes dessa rede (crianças, professoras, pesquisadores, artefatos, bosque, pistas) estão mobilizados para descobrir a história que 0 bosque tem para contar.

Fonte: Elaborado pelos autores deste trabalho.

\section{Mobilizando corpos, registrando novas realidades}

Depois de examinar e guardar o material no saco plástico, Gustavo se depara com o muro do bosque repleto de marcas de mãos feitas pelas crianças. Nesse momento, estabelece-se um diálogo entre Gustavo, pesquisadora e professora, conforme transcrito no Trecho $1 .{ }^{6}$

Trecho 1. 20m35s.

Gustavo: OLHA AQUI, MINHA GENTE! Uma mão!

Pesquisadora: Olha!

Professora e pesquisadora: Tira foto! Tira foto!

[Gustavo e Eliana se aproximam do muro. Gustavo tira uma foto]

Pesquisador: Aí, esta pista, a gente não consegue guardar ela; então a gente vai só tirar a foto. Gustavo: (inaudível) Agora eu vou achar outra coisa.

Nesse momento, Gustavo e Eliana começam a dar sentido ao que veem e ao que tocam. A madeira e as marcas das mãos no muro começam a ganhar novos significados. Eles iniciam uma tarefa de abstração, transformando coisas em signos (LATOUR, 2001). Ao dizer "Olha aqui, minha gente! Uma mão!", podemos inferir, pela entonação de sua fala, que Gustavo está perplexo com sua descoberta. Para ele, o muro do bosque da escola também se transforma em signo. As marcas 
de mãos feitas com o barro no muro, fruto de uma brincadeira, se transformam em sinais, em pistas que fazem com que o nosso pequeno desbravador vá articulando, por meio das palavras, de sua câmera, de sua colega e também dos pesquisadores, uma história vivida por outras crianças no dia anterior. Essa descoberta afeta Gustavo, que se mobiliza para prosseguir em sua investigação: "Agora eu vou achar outra coisa."

Gustavo e Eliana se afastam daquele local. Eles permanecem fora das imagens capturadas pela câmara por 45 segundos. Ao retornar, vemos Gustavo caminhando pelo bosque com Eliana, o saco plástico em mãos, contendo brinquedos de plástico recolhidos pela dupla, que interage com a professora e o pesquisador. Em seguida, eles se afastam dos adultos novamente, dizendo que irão achar outras coisas. Eliana sugere procurar ao redor da árvore, sugestão que é descartada por Gustavo, que diz que ali não tem pistas. Eliana permanece explorando ao redor da árvore enquanto Gustavo se afasta. Ele percebe que Eliana fica para trás e a chama para explorar outra parte do bosque. O menino já entende que o bosque se transformou: ali (ao redor da árvore) não tem pistas. Não será produtivo explorar aquele lugar. Para ele, o bosque não é mais um lugar de brincadeiras e sim um espaço de investigação. O espaço, o entorno, afeta Gustavo, que já faz escolhas e julgamentos tendo por base um novo referencial ("aí não tem pistas").

Gustavo prossegue e olha para o chão pelas lentes da câmera. Menino e câmera se misturam, se hibridizam. Transformam-se em um novo actante. O novo "meninocâmera" tem seu corpo afetado: levemente curvado, olhos voltados para o chão, olhar que atravessa as lentes da câmera fotográfica. Esse momento pode ser visto na Figura 5.

FIGURA 5 - "Meninocâmera"

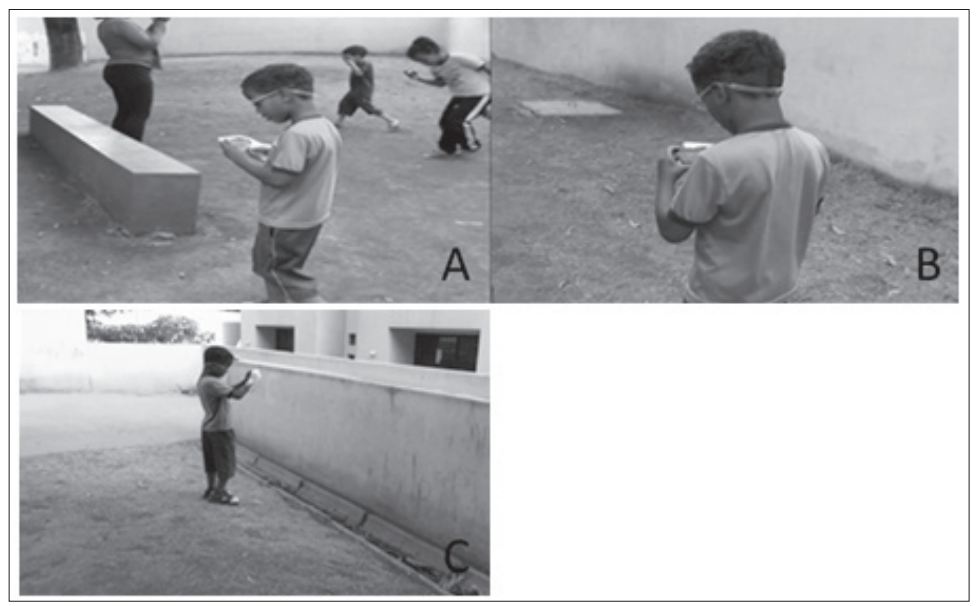

Legenda: 0 híbrido Gustavo e câmera em ação. Seu olhar agora perpassa 0 artefato cultural (A, B e C). Fonte: Elaborado pelos autores deste trabalho. 
Juntamente com Eliana, vai explorando outras áreas do bosque e se depara com vários gravetos dispostos como se fosse uma fogueira. Ele fotografa seu achado (Figura 6), interage com a pesquisadora e solicita ajuda da professora. Eles conversam sobre a possibilidade de ser uma fogueira que poderia ser acesa com o fogo feito a partir da fricção de duas pedras. Concluem serem galhos e coletam uma pequena amostra colocando-a no saco de plástico. Os dois se afastam do local, encontram com outra dupla e comunicam seu achado: "uma fogueira!" As quatro crianças trocam informações sobre o que acharam. A essa altura, podemos dizer que já temos indícios fortes de que a dupla foi afetada pela atividade de busca de pistas no bosque. "Agora vou procurar outra coisa", diz Gustavo que se afasta novamente olhando para o chão através das lentes da câmera fotográfica. Nosso "meninocâmera" está impregnado por instrumentos, materiais, sentidos, pessoas. A tarefa de abstração, de transformação de coisas em signos prossegue.

FIGURA 6 - Gustavo e Eliana encontram mais uma pista

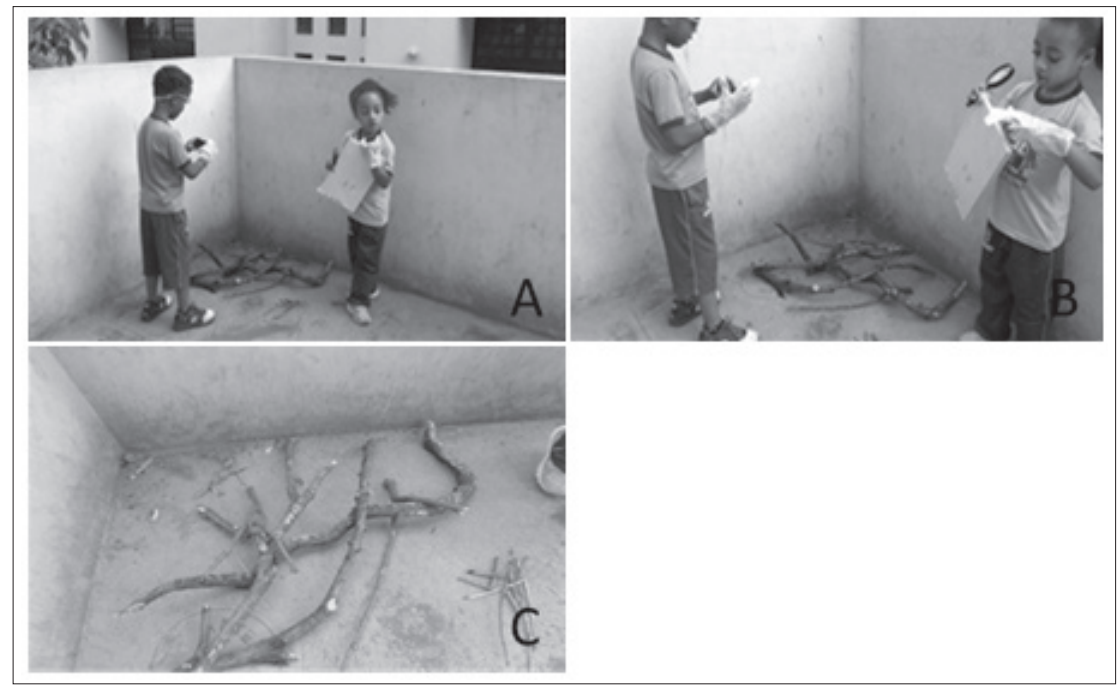

Legenda: uma porção de gravetos agrupados que eles deduzem ser uma fogueira (A e B). Fotografia tirada pela criança (C).

Fonte: Elaborado pelos autores deste trabalho.

Gustavo e Eliane caminham pelo pátio - ele, na frente, olhando o chão através da lente da câmera e ela, um pouco mais atrás, empunhando sua lupa, carrega o saco contendo o material coletado. Caminhando atento, algo chama lhe chama a atenção. Ele afasta o olhar da cena e caminha um pouco mais. Ao olhar para trás para chamar sua dupla: "Vem aqui, Eliane", Gustavo percebe algo. Vira todo seu corpo 
e sai correndo em direção ao objeto que lhe chamou a atenção. Gustavo grita: "O que é isso?" (Veja-se a sequência no conjunto de fotos da Figura 7). Ele corre e se depara com uma formação de pequenas pedras e uma pequena manga enfileiradas no chão (Figura 8).

\section{Trecho 2. $25 \mathrm{~m} 45 \mathrm{~s}$.}

Gustavo: O QUE É ISSO? Olha isso aqui [apontando para o chão e falando para os pesquisadores. Eliana corre junto com Gustavo]. Outra pista.

Pesquisadora: O quê?

[Gustavo abaixa e fotografa a fileira de pedras. Recolhe um dos objetos e o coloca no saco plástico].

Pesquisadora: Isso, põe no seu saquinho. O que é isso que você achou aí?

Gustavo: Ué! Eu acho que é uma pista.

[O pesquisador se aproxima e interage com Gustavo].

Pesquisador: $\mathrm{O}$ quê? $\mathrm{O}$ quê que isso parece?

Gustavo: Uma manga.

Pesquisador: Uma manga?

Pesquisadora: Parece uma manguinha?

FIGURA 7 - Momento em que Gustavo percebe uma alteração no ambiente que pode ser uma pista

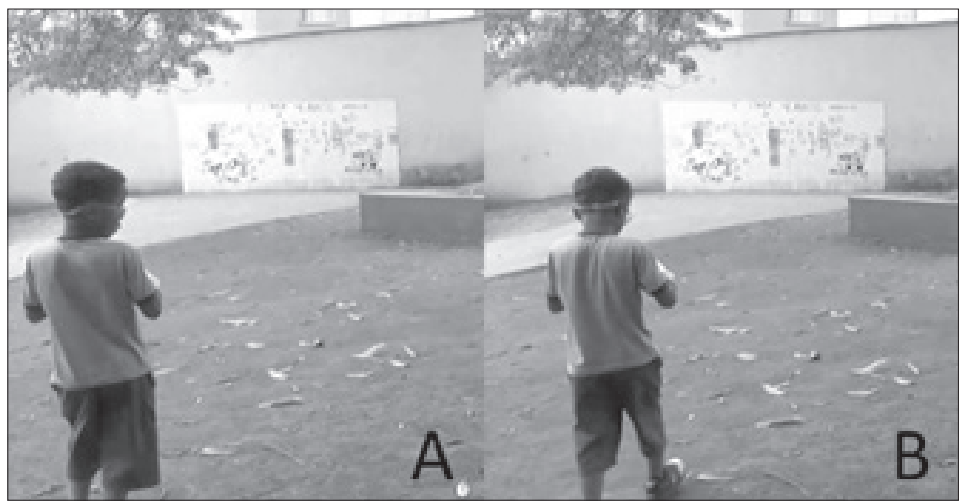


19

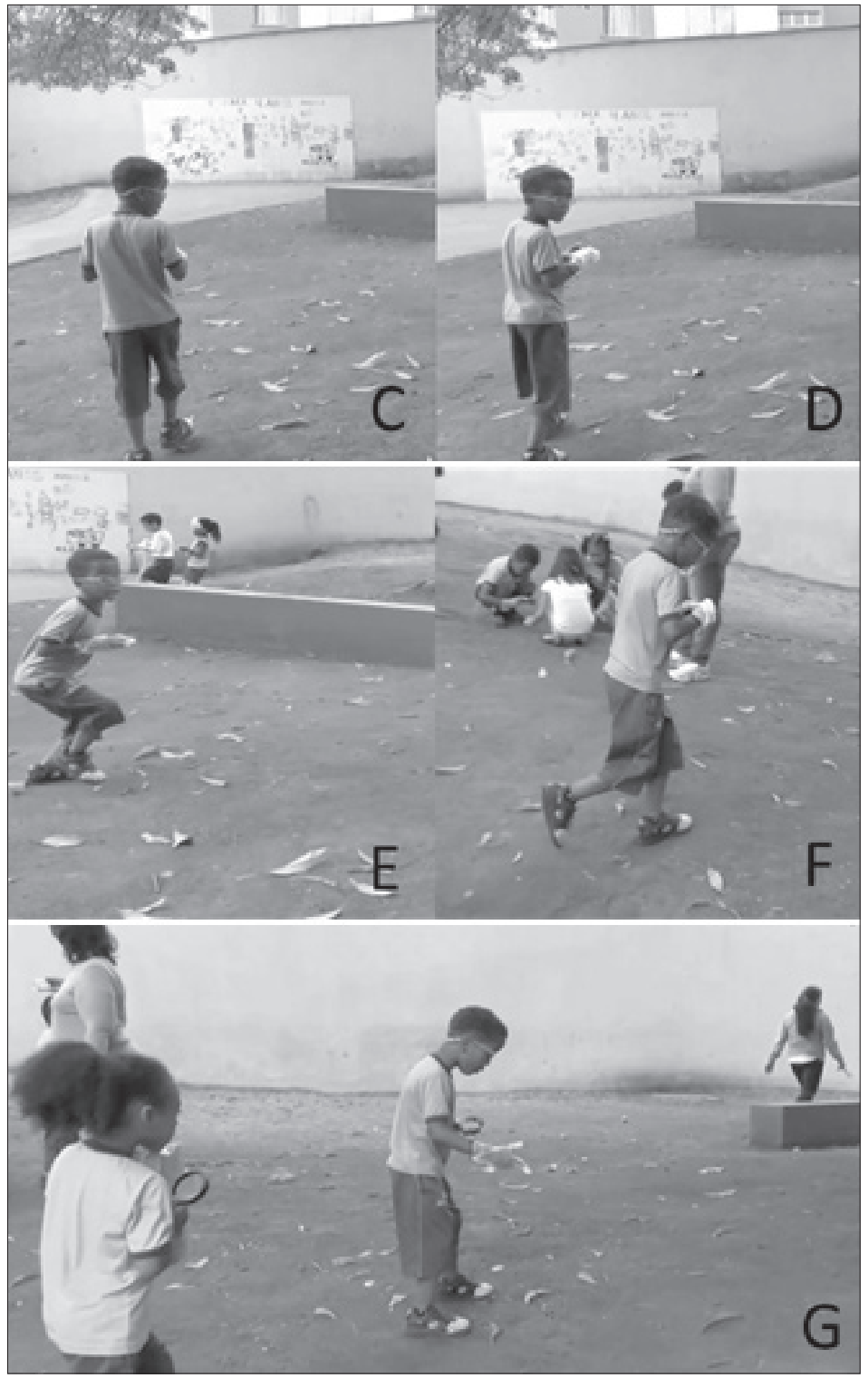

Fonte: Elaborado pelos autores deste trabalho 
FIGURA 8 - Gustavo se depara com a fileira de pedras

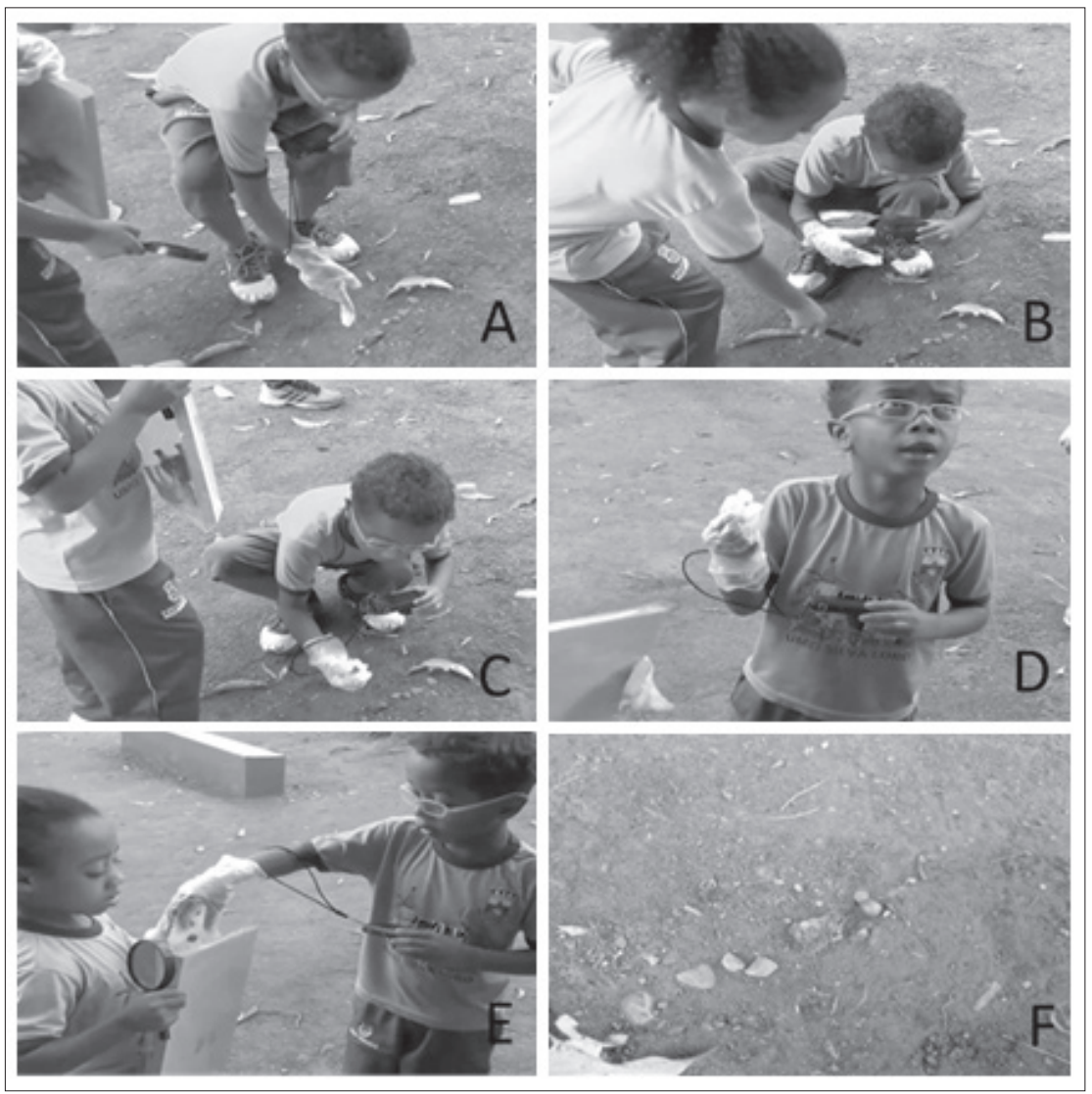

Legenda: Aqui Gustavo demonstra que sua atenção está voltada para aspectos específicos do ambiente. Ainda, ele observa (A), inclusive utilizando um gesto dêitico (delimitando o foco de atenção), registra $(B)$ e coleta 0 material encontrado (C, D, E). Em F mostramos a pista encontrada por Gustavo.

Fonte: Elaborado pelos autores deste trabalho.

Gustavo está imerso na tarefa de achar pistas. Seu corpo, sua percepção, seu olhar, seu instrumento (a câmera fotográfica) e seu encantamento estão completamente voltados para o cumprimento da tarefa. Os pesquisadores, entretanto, encontram-se engajados na tarefa de observar as crianças, e não as pistas. Com isso, nenhum deles se atenta para o detalhe de que as pedras, ou pequenas mangas, estão enfileiradas: o que pode ser um indício de terem sido colocadas ali propositadamente por algum adulto ou criança, no intuito de deixar uma pista. Gustavo parece perceber isso de imediato, uma vez que denomina seu achado como "uma pista". Ele está inteiro na 
tarefa. Entretanto, os comentários dos pesquisadores contradizem o que a criança observa. Eles alegam que é uma pista da natureza: uma pequena manga que caiu da árvore aleatoriamente. Gustavo tira uma foto e estoca o pequeno fruto no saco de plástico. A criança já sabe o que faz e não se perturba com o comentário impróprio dos adultos. Ele já foi afetado e o que emerge, no comentário dos adultos, não é suficiente para fazê-lo vacilar. Somente depois, pela foto tirada por Gustavo, é que os pesquisadores percebem ser esta uma pista deixada pelas crianças.

Gustavo se afasta do local, ficando longe do alcance da filmadora por dois minutos. Quando ele e Eliane aparecem, estão participando do achado de alguns colegas: marcas de pegadas no chão. Todos discutem sobre a procedência da pegada. Quem teria feito? Seria uma pegada deixada propositadamente, como uma pista, ou impressa no chão aleatoriamente, resultado de suas próprias caminhadas pelo bosque? As crianças se afastam e acabam achando um passarinho ferido que é recolhido pelo pesquisador e observado pelas crianças. Cerca de dois minutos depois, vemos novamente a dupla Gustavo e Eliana observando e fotografando o passarinho. Gustavo anuncia novamente que irá continuar procurando mais pistas. Acha uma manga apodrecida no chão. Fotografa, recolhe e a coloca no saco plástico. Ele acha, ainda, um pedaço de cadarço que fotografa e recolhe. A atitude de pesquisa de Gustavo prossegue. Passos lentos, olhos atentos através das lentes da câmera, corpo inclinado para o chão. Algumas crianças percebem agora marcas de mãos no muro do bosque, que foram observadas por Gustavo logo no início do episódio (aos 20min35s) e mostram para o pesquisador. A professora chama as crianças para retornarem à sala de aula.

Aos $35 \mathrm{~min} 06 \mathrm{~s}$, logo após a professora anunciar o retorno para a sala de aula, vemos Gustavo sozinho, totalmente concentrado na tarefa de fotografar o muro. A pesquisadora aproxima-se do garoto e o interroga: "O que você está fotografando aí?" Nesse momento, o menino observa acuradamente as marcas de mãos feitas no muro do bosque (Figura 9). 
FIGURA 9 - Momento em que Gustavo se depara com as marcas no muro

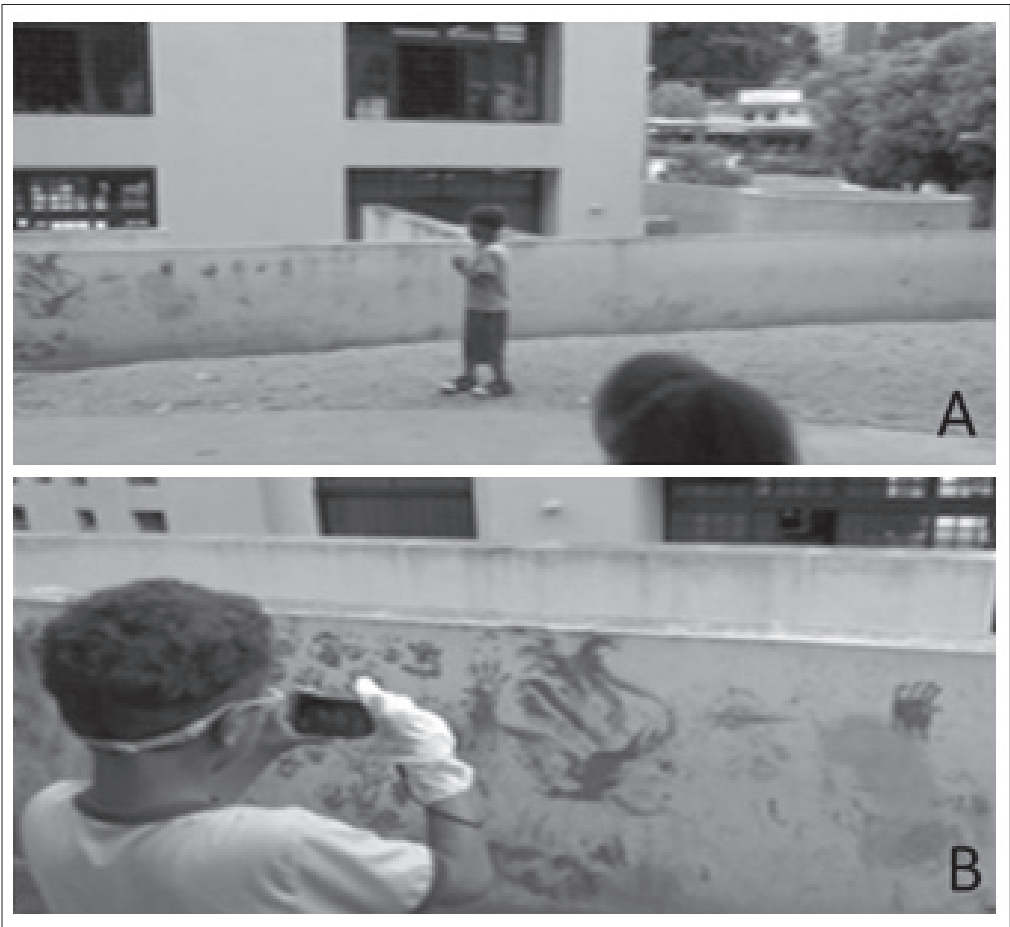

Legenda: As marcas no muro mobilizam a atenção da criança (A). A seguir, o momento em que a criança mobiliza seu artefato cultural para registrar 0 que observa (B).

Fonte: Elaborado pelos autores deste trabalho.

Gustavo prossegue sua investigação, agora com mais atenção. Através das lentes de sua câmera fotográfica, o "meninocâmera" percebe que as marcas das mãos fazem um movimento no muro, indo de uma extremidade à outra. Nesse instante, ele corre até o corredor de entrada do bosque e aponta para outras marcas de barro na parede, estabelecendo diálogo com a pesquisadora, conforme o Trecho 3.

Trecho 3. 35min36s:

Pesquisadora: $\mathrm{O}$ quê que você viu?

Gustavo: Na terra, uma mão na terra até ali.

Pesquisadora: Mãos. Ah, as mãos vão chegando até aqui, é isso?!

Gustavo: Não, ela acabou até aqui ó [apontando para o final das marcas de mão].

Pesquisadora: Entendi, então é a mão (interrompe a fala).

Gustavo: OLHA!! (inaudível) [ele corre até o outro lado do muro].

Gustavo: Vai até aqui ó [apontando para o outro lado do muro].

Pesquisadora: Vai até aî́!

[Gustavo registra a última marca de terra na parede tirando fotos]. 
As marcas de mãos feitas na parede saltam aos olhos de Gustavo. Elas o atraem e o menino segue seu percurso (Figura 10). Há um diálogo íntimo e silencioso entre elas e o garoto e outro diálogo de superfície entre o garoto e a pesquisadora. Diálogos que possibilitam uma coalizão ontológica entre a criança, o muro, as marcas e a pesquisadora. Gustavo toma a iniciativa nessa conversa expressa e silenciosa ao mesmo tempo. Ele corre daqui e dali, aponta, observa, retrata, constata. E prossegue, conforme o Trecho 4.

Trecho 4. 36min $18 \mathrm{~s}$

Gustavo: NOSSA! O que que é isso? [continua fotografando].

[Gustavo permanece 4 segundos em silêncio observando e conclui]:

Gustavo: Eu não sei o que é isso aqui (inaudível)

[Mais 3 segundos se passam e ele reflete, concluindo]:

Gustavo: $\mathrm{Oh}$, eu acho que o menino desenhou até aqui e ele foi correndo até aqui assim.

Pesquisadora: $\mathrm{O}$ menino, o que?

Gustavo: Ele pintou isso aqui.

Pesquisadora: $\mathrm{O}$ menino pintou até aí?

Gustavo: Ele pintou até aqui, até aqui.

Pesquisadora: Até aí.

[Gustavo se vira e olha para o outro muro].

Gustavo: Ele pintou até aqui. OLHA!!! Aqui ó.

[Ele aponta para o outro muro do corredor que apresenta manchas de mofo].

Pesquisadora: E essa pista aí, será que foi o menino que pintou?

Gustavo: (inaudível)

Pesquisadora: Isso aí é o que?

[Gustavo balança os ombros, sinalizando que não sabe].

Pesquisadora: Então fotografa, pra depois a gente descobrir o que é isso.

Pesquisadora: Muito interessante!

FIGURA 10 - Movimento da rede híbrida e emergência da aprendizagem
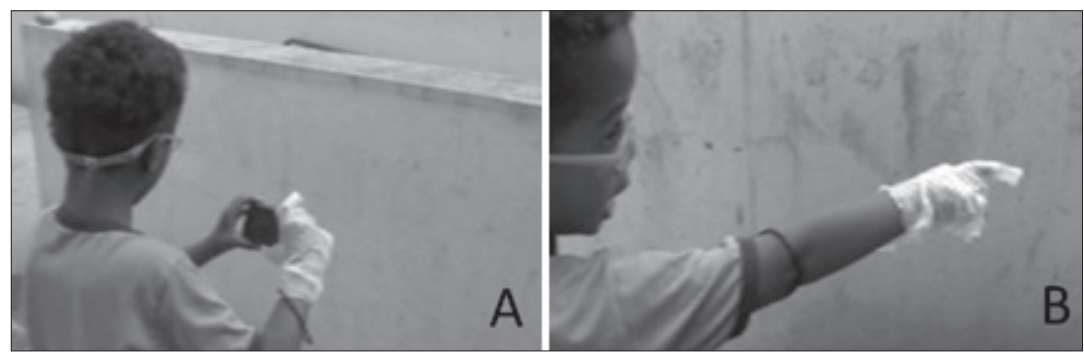


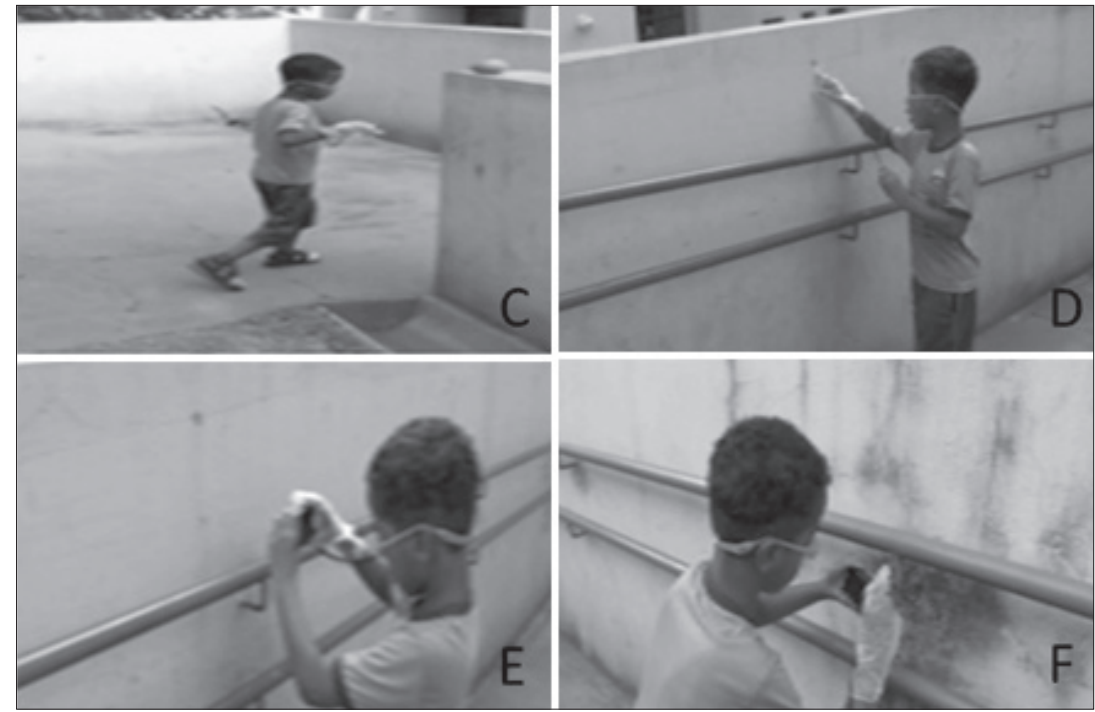

Legenda: A criança registra as últimas marcas de barro no muro (A). Ela indica o movimento das marcas no muro - da direita para esquerda (B). A seguir, ao observar mais marcas de barro no outro muro (do corredor), corre até lá (C). Gustavo analisa e registra a nova marca descoberta (D,E). Por último, ele registra a nova marca (do mofo), agora desconhecida no muro oposto do corredor (F).

Fonte: Elaborado pelos autores deste trabalho.

Gustavo prossegue sua investigação. Ele se espanta, se entusiasma. Está em plena atividade corporal, intelectual, emocional. Observa, compara, levanta hipóteses, coleta dados que ainda estão obscuros para ele. Mesmo não sabendo nomear, Gustavo identifica a diferença das marcas das mãos e as do mofo. Podemos observar a força dos actantes (menino, pesquisadora, artefatos culturais, muro, marcas, espaço físico etc.) de forma a criar e estabilizar uma rede de onde emergem aprendizagens.

\section{O SINAL QUE SE TRANSFORMA EM PISTA: EFEITOS DA REDE QUE GERAM CONHECIMENTOS}

Eliane finalmente se junta à sua dupla. Gustavo interage com ela, mostrando as marcas de mofo na parede. Aqui, podemos dizer que, provavelmente, esse bosque nunca expôs seus segredos a humanos tão disciplinados e engajados. Os dois examinam as fotos tiradas por Gustavo, observam novamente o muro, tiram novas fotos. Gustavo não se cansa (Figura 11). 
FIGURA 11 - Gustavo e Eliane examinam as fotos e o mofo na parede

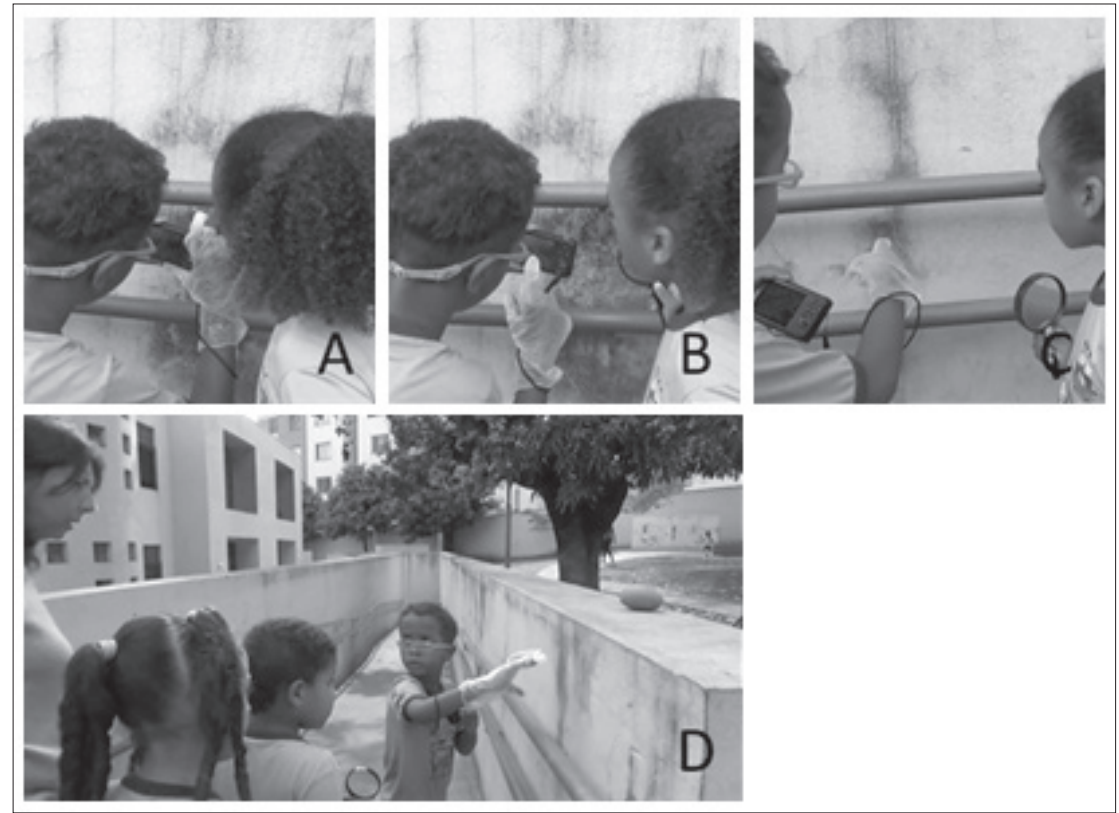

Legenda: Note-se (em D) Gustavo apresentando a nova pista para a professora.

Fonte: Elaborado pelos autores deste trabalho.

Gustavo e Eliane começam a encontrar pistas em todos os lugares. Observam uma teia de aranha no corrimão e tiram fotos. Eliane acompanha Gustavo, examinando com sua lupa. Eles retornam ao bosque à procura do saco plástico contendo seu material coletado. Relatam para a professora que coletaram muitas coisas. Gustavo chama a professora para mostrar seu achado. Ela o acompanha até a rampa de descida do bosque onde Gustavo lhe apresenta as marcas de mofo no muro (Figura 11). As crianças exploram um pouco mais o bosque. Gustavo fotografa novamente o muro cheio de marcas de mãos. As crianças descem pela rampa para a sala de aula. Na descida, Gustavo observa novas marcas na parede e fotografa.

Trecho 5. 42min15s

Pesquisador: O que é isso Gustavo?

Gustavo: Eu achei!

Eliane: Nós dois.

Pesquisador: Você acha que foram os meninos que fizeram isso?

[Gustavo corre até a parede lateral do refeitório].

Gustavo: OLHA!! 
[Na parede estão desenhadas, com caneta hidrocor, duas figuras: um triângulo e uma seta. Gustavo tira uma foto das figuras enquanto Eliane o segue observando os desenhos com a lupa]. Pesquisador: O que é isso, Gustavo?

Eliane: Uma seta

Gustavo: Vou tirar foto.

Pesquisador: Uma seta?

Gustavo: Uma seta. Uma seta apontando pra lá.

[Gustavo tira mais uma foto. Todas as crianças continuam andando em direção à sala de aula. Ao subir as escadas que dão para o andar superior, Gustavo aponta]:

Gustavo: OLHA!!

[Gustavo tira uma foto de uma mancha de tinta no degrau da escada e sobe para a sala de aula].

Gustavo se encontra totalmente imerso e afetado pela investigação que realizou. As pistas saltam-lhe aos olhos. Ele as encontra em todos os lugares. Não apenas no bosque, mas também nas paredes do refeitório, nas escadas que dão acesso à sua sala de aula. Com isso, temos indícios fortes de que a rede sociomaterial se estabilizou, permitindo emergir novos achados, novas aprendizagens. Gustavo foi impregnado pela ideia de pista e a usa para dar sentido às inscrições que observa na escola: "Uma seta. Uma seta apontando para lá!" Aqui temos uma evidência de que o menino já percebe que essa é uma inscrição deixada por alguém e que, provavelmente conta uma história (Figura 12).

FIGURA 12 - Gustavo e Eliane observando outras "pistas" pela escola

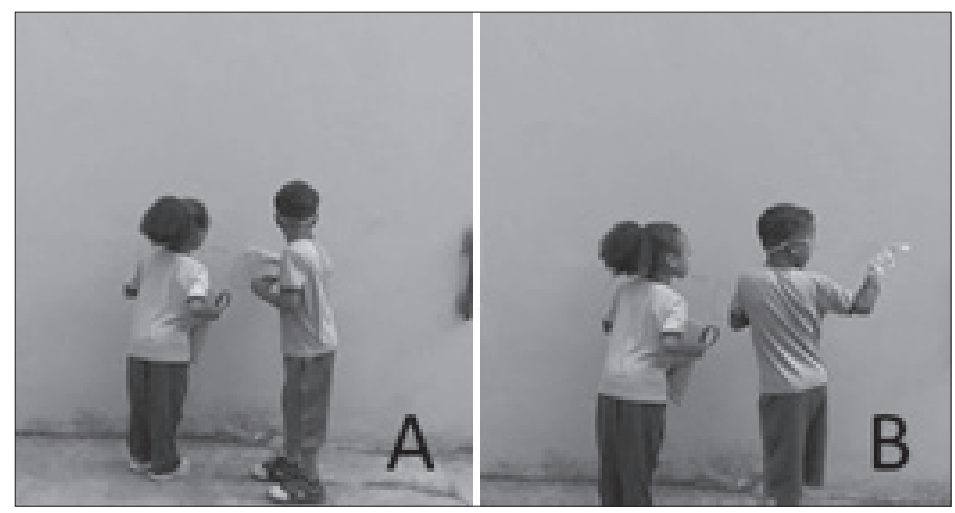




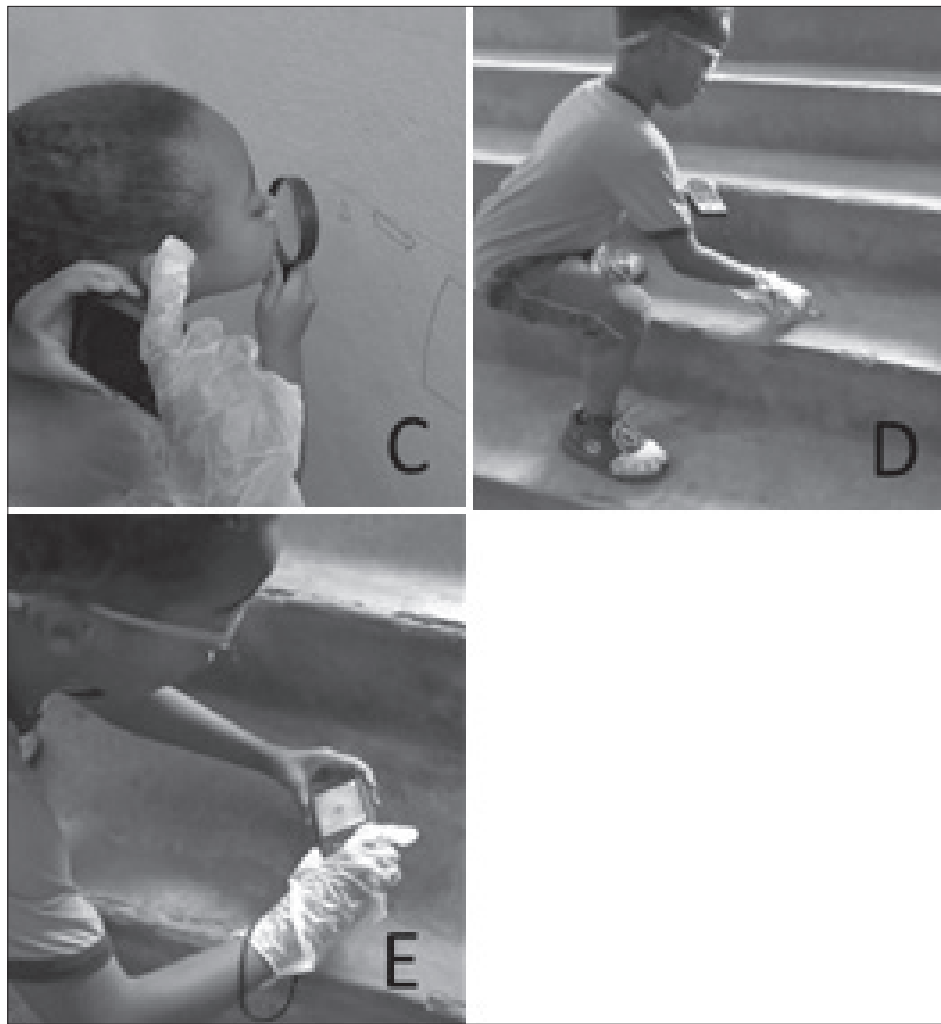

Legenda: Momento em que Gustavo percebe uma inscrição, uma seta (A), e decide seguir a nova pista. Veja-se que Gustavo foca sua atenção no sentido da seta (B) e aproxima-se para analisar a pista com maior acuidade (C). Em D e E, Gustavo registra as pistas encontradas na escada indicada pela seta.

Fonte: Elaborado pelos autores deste trabalho.

Gustavo e Eliane empreenderam uma complexa tarefa de transformar coisas em signos. Eles operaram transições das mãos, da parede, da tinta em um primeiro signo, as fotos, que foram compreendidas como pistas. Esses atos de referência produzem uma série regulada de transformações, transmutações, translações (LATOUR, 2001). Nesse espaço do bosque, que agora emerge como espaço de investigação, as coisas ali deixadas - marcas das mãos, pequenas mangas, pedaços de gravetos dispostos como uma fogueira - sofrem uma cadeia de translações que faz com que o significado tenha maior durabilidade. Por exemplo, a pequena manga, extraída da série, passa do chão à foto e desta ao saco de plástico, em seguida, à sala de aula. Gustavo e Eliane transformam mangas, mãos, gravetos em ideias. A ideia de pista. A ideia de que a pista conta uma história. 
Para ser afetada, a criança passa por essa cadeia. No nosso exemplo, a cadeia de transformações se inicia pela materialidade - a tinta, as mãos, o muro - que se torna signos - a foto, a fala -, passando pela organização do material em sala de aula, pelas classificações das diversas pistas até chegar à história narrada pelo material. A cada transformação, ideias vão surgindo. Todo esse percurso afeta a criança. É esse o percurso do aprendizado.

\section{CONSIDERAÇÕES FINAIS}

Nossos resultados indicam que a exploração do mundo pelas crianças pode ser realizada de modo sistemático, configurando investigações que envolvem observação, coleta, categorização de elementos humanos e não humanos e transformação de objetos tecnológicos em instrumentos de pesquisa e investigação, como no caso da câmera fotográfica, das luvas e dos sacos plásticos.

Ao atentarmos para a ideia de que aprendizagem não é simplesmente aquisição conceitual ou de esquemas mentais, fomos capazes de perceber as crianças como corpos que são capazes de ativamente explorar o mundo ao seu redor. Porém, mais do que isso, o estudo aqui realizado mostrou como a aprendizagem foi possível graças ao desenvolvimento da habilidade das crianças de serem afetadas pelos elementos humanos e não humanos envolvidos na rede que se formou no bosque da escola.

Assim, consideramos que nossos achados fornecem subsídios para a construção de atividades relacionadas à aprendizagem de ciências por crianças pequenas. Quanto a investigações futuras, consideramos que estamos assentados sobre um importante e promissor referencial teórico-metodológico. Muito ainda há o que ser feito. Uma primeira necessidade é de aprofundamento do conceito de afetação. Isso é importante, pois precisamos de maior clareza para a construção de instrumentos metodológicos sobre a análise da educação da atenção em processos de ensino/aprendizagem de ciências.

Em segundo lugar, há a necessidade de maiores investimentos conceituais e empíricos para estabelecermos abordagens mais ontológicas e menos epistemológicas da aprendizagem. Nesse sentido, urge completar a teoria ator-rede com aportes das concepções sobre cognição situada e cognição distribuída. Finalmente, esperamos que o que aqui foi exposto encontre ecos na comunidade de educadores e que nossa proposta possa ser avaliada, completada e aperfeiçoada. 


\section{AGRADECIMENTOS}

O primeiro autor é grato ao $\mathrm{CNPq}$ pela bolsa de produtividade de pesquisa e pelo apoio financeiro. $\mathrm{O}$ segundo autor é grato à FAPEMIG e à CAPES pelo apoio financeiro. Nossos agradecimentos também à direção e coordenação da Unidade Municipal de Educação Infantil, às professoras e às crianças, que compartilharam conosco desta pesquisa. Agradecemos também ao grupo que participou diretamente da pesquisa: Márcia Cabral, Júnia Costa, Katiane Oliveira, Natália Ribeiro e Débora Reis pelas discussões e colaborações. Ao Grupo de Estudos Integrados (GEI), pela construção conjunta do trabalho. Os autores são gratos, ainda, aos revisores anônimos pelas contribuições.

\section{REFERÊNCIAS}

BARBOSA, A. M. Culturas da infância nos espaços-tempos do brincar: estratégias de participação e construção da ordem social em um grupo de crianças de 4-6 anos. Momento, Rio Grande, v. 18, p. 35-50, 2007.

BENNETT, J. Vibrant matter: A political ecology of things. Durham: Duke University Press, 2010.

BLOK, A.; JENSEN, T. E. Bruno Latour: hybrid thoughts in a hybrid world. London: Routledge, 2011.

CAPECCHI, M. C. M.; CARVALHO, A. M. P. Atividades de laboratório como instrumentos para a abordagem de aspectos da cultura científica em sala de aula. Pro-Posições, Campinas, v. 17, n. 1, p. 137-153, 2006.

CARVALHO, A. M. P. Habilidades de professores para promover a enculturação científica. Contexto \& Educação, Panambi, v. 77, p. 25-49, 2007.

CORSARO, W. A reprodução interpretativa no brincar ao faz de conta das crianças. Educação, sociedade \& culturas, Porto, n. 17, p. 113-134, 2002.

CORSARO, W. The sociology of childhood. California: Pine Forge Press, 1997.

COUTINHO, F. A. et al. Seguindo uma lupa em uma aula de ciências para a Educação Infantil. Investigações em Ensino de Ciências, [S.I], v. 19, n. 2, p. 381-402, 2014.

DRIVER, R. et al. Constructing Scientific Knowledge in the Classroom. Educational Researcher, Abingdon, v. 23, p. 05-12, 1994.

EDWARDS, D; MERCER, N. Common Knowledge: the development of understanding in the classroom. London: Methuen, 1987.

FENWICK, T. EDWARDS, R.; SAWCHUK, P. Emerging approaches to educational research. London: Routledge, 2011.

FOX, S. Contexts of teaching and learning. An actor-network view of the classroom. In: EDWARDS, R.; BIESTA, G.; THORPE, M. Rethinking Contexts for Learning and Teaching: Communities, Activities and Networks. New York: Routledge, 2009. p. 31-43.

FRENCH, L. A.; WOODRING, S. D. Science education in the early years. In: SARACHO, O. N. E. SPODEK, B. Handbook of research on the education of young children. New York: Routledge, 2013, p. 179-196. 
GOULART, M. I. M; ROTH, W-M. Engaging young children in collective curriculum design. Cultural Studies of Science Education, Rotterdam: Springer, v. 5, p. 533-562, 2010.

HARMAN. G. Prince of networks: Bruno Latour and metaphysics. Melbourne: Re. Press, 2009. HODSON, D.; HODSON, J. Science education as enculturation: some implications for practice. School Science Review, v. 80, n. 290, p. 17-24, 1998.

HUTCHINS, E. Cognition in the wild. Cambridge: MIT Press, 1995.

IBIPAINA, I. Pesquisa colaborativa: investigação, formação e produção de conhecimento. Brasília: Líber Livro, 2008.

INGOLD, T. Da transmissão de representações à educação da atenção. Educação, Porto Alegre, v. 33, n. 1, p. 6-25, 2010.

LATOUR, B. A esperança de Pandora: ensaio sobre a realidade dos estudos científicos. São Paulo: Bauru, 2001.

LATOUR, B. Ciência em ação: como seguir cientistas e engenheiros sociedade afora. São Paulo: UNESP, 2000.

LATOUR, B. Gabriel Tarde and the end of the social. In: JOYCE, P (Ed.) The Social in Question: New Bearings in the History and the Social Sciences. London: Routledge, 2002. p. 117-32.

LATOUR, B. How to Talk About the Body? The Normative Dimension of Science Studies. Body \& Society, Califórnia: Sage, v. 10, n. 2-3, p. 205-229, 2004.

LATOUR, B. Jamais fomos modernos. Rio de Janeiro: Editora 34, 1994.

LATOUR, B. Reassembling the Social. Oxford: Oxford University Press, 2005.

METZ, K. E. Reassessment of Developmental Constraints on Children's Science Instruction. Review of Educational Research, Califórnia: Sage, v. 65, n. 2, p. 93-127, 1995.

MORTIMER, E. F. Addresing obstacles in the classroom: an example from theory of matter. In: EUROPEAN CONFERENCE ON RESEARCH IN SCIENCE EDUCATION, 1., 1995. Leeds. Anais do ESERA. Leeds: University of London, 1995.

MORTIMER, E. F. Linguagem e formação de conceitos no ensino de Ciências. Belo Horizonte: Editora UFMG, 2000.

MORTIMER, E. F.; CARVAlHO, A. M. P. Referenciais Teóricos Para Análise do Processo de Ensino de Ciências. Cadernos de Pesquisa, São Luis, v. 96, p. 5-14, 1996.

NEWMAN, D.; GRIFFIN, P.; COLE, M. The construction zone: Working for cognitive change in school. Cambridge: Cambrige University Press, 1989.

NIEDDERER, H.; GOLDBERG, F.; DUIT, R. Towards Learning Process Studies: A review of the Workshop on Research in Physics Learning. In: DUIT, R.; GOLDBERG, F.; NIEDDERER, H. (Ed.). Research in Physics Learning: Theoretical Issues and Empirical Studies. Kiel: IPN, 1991. 10-28.

PINTO, M.; SARMENTO, M. As crianças: contextos e identidades. Braga: Centro de Estudos da Criança, 1997.

POSNER, G. J. et al. Accommodation of a scientific conception: Toward a theory of conceptual change. Science Education, New Jersey: Wiley, v. 66, p. 211-227, 1982.

PROUT, A. Reconsiderando a nova sociologia da infância. Cadernos de Pesquisa, São Luis, v. 40, n. 141, p. 729-750, 2010.

PROUT, A. The future of childhood. London: Routledge, 2005.

ROMANELLI, L. I. Concepções do professor sobre o seu papel mediador na 
construção do conhecimento do conceito de átomo. 1992. 226 f. Tese (Doutorado em Educação) - Faculdade de Educação, Universidade Estadual de Campinas, Campinas, 1992. ROTH, W. M.; GOULART, M. I.; PLAKITSI, K. Science Education during early childhood: a Cultural-historical perspective. Heidelberg: Springer, 2013.

SCOTT, P. H. Planning Secondary School Teaching with Children's thinking in Mind. In: BRITISH EDUCATIONAL RESEARCH ASSOCIATION, 18., 1992. Stirling. Anais do XVIII BERA. Stirling: BERA, 1992.

SISMONDO, S. An introduction to science and technology studies. Oxford: WileyBlackwell, 2010.

\section{NOTAS}

1 “"...] a major barrier to teaching Science in early childhood has been a reliance on Piagetian theory as the primary framework for understanding children's development combined with a definition of Science that involves some combination of abstract principles and controlled experimentation with multiple variables." (FRENCH; WOODRING, 2013, p. 182)

${ }^{2} \mathrm{O}$ termo actante deriva do trabalho semiótico de Algirdas Greimas, segundo o qual qualquer palavra é definida completamente em termos de suas relações a outros termos linguísticos. Latour estende e aplica essa visão relacional a todos dos os tipos de entidades (materiais, atores humanos, eventos etc.). Por isso, a teoria ator-rede também é conhecida como semiótica material (BLOCK; JENSEN, 2011, p. 17, 167).

${ }^{3}$ Outro problema que surge com a ideia de enculturação, segundo Ingold (2010), é seu compromisso com o pressuposto de uma primazia da cultura como um estoque de informação e a visão de que os seres humanos são dispositivos para processá-la.

${ }^{4}$ A este respeito, veja-se também Latour (2002).

${ }^{5}$ Os nomes dos sujeitos envolvidos na pesquisa são fictícios, por recomendação do Comitê de Ética em Pesquisa da UFMG.

${ }^{6}$ Para a transcrição, usamos as seguintes convenções: Gestos e ações significativas foram registrados usando um colchete, por exemplo: [Gustavo e Eliana se aproximam do muro]. Notas dos autores em relação à qualidade dos dados foram registradas usando parênteses, por exemplo: (inaudível). Ênfases nas falas denotando aumento do volume foram registradas em caixa alta, como em: OLHA!!. Pontuações foram usadas para indicar características do discurso: .,;!

Submetido: $21 / 10 / 2015$

Aprovado: 16/06/2016

Contato:

Universidade Federal de Minas Gerais (UFMG) FaE - Faculdade de Educação Francisco Ângelo Coutinho Av. Presidente Antônio Carlos, no 6627 - Pampulha, Belo Horizonte |MG|Brasil CEP 31.270-901 